\title{
Comparison of Contextual and Scientific Approaches to Improving Student Achievement and Emotional Intelligence
}

\author{
Nani Maryani ${ }^{1, *}$ Djamilah B. Widjajanti ${ }^{2}$ \\ ${ }^{1}$ Mathematics Education, Graduate Program, Yogyakarta State University, Indonesia \\ ${ }^{2}$ Mathematics Education, Faculty of Mathematics and Science, Yogyakarta State University, Indonesia \\ *Corresponding author.Email: nmaryani171196@gmail.com; nanimaryani.2018@student.uny.ac.id
}

\begin{abstract}
This research was quasi-experimental, with a nonequivalent control-group design. This study aimed to compare the advantages of contextual and scientific approaches in improving the learning achievement and emotional intelligence of grade VIII junior high school students. The population includes all grade VIII students of MTsN (State Islamic Junior High School) 1 Boyolali, Central Java, Indonesia. The sample of this study was 37 students of class VIII G and 36 students of class VIII C at MTsN 1 Boyolali. Learning achievement test instruments and emotional intelligence questionnaires are valid and reliable. Data were analyzed using a significance level of $\alpha=5 \%$. The results of this study indicate that 1) the scientific approach was better than the contextual approach in improving junior high school students' learning achievement on solid geometry, 2) there was no difference in the superiority of the scientific and contextual approaches in terms of increasing students' emotional intelligence.
\end{abstract}

Keywords: Contextual approach, Scientific approach, Student achievement, Emotional Intelligence.

\section{INTRODUCTION}

The 2013 curriculum recommends teachers use a scientific approach, including for learning mathematics. Previously, many mathematics teachers had used a contextual approach. The question arises from the teachers, whether the scientific approach is better than the contextual approach. A contextual approach is a learning approach that helps teachers to connect subjects with students' daily lives. Contextual learning steps include: (1) Relating; (2) Experiencing; (3) Applying; (4) Cooperating; and (5) Transfering [1], [2]. According to Smith [3], the contextual approach has several advantages, namely: (1) students are more active in the learning process; (2) students learn from each other through cooperation, teamwork, and self-reflection; (3) students learn to be responsible for monitoring and developing their learning; (4) students feel valued and respected; (5) students obtain assessments from teachers in various ways.
A scientific approach is a learning approach that consists of (1) observing; (2) asking; (3) collecting information; (4) reasoning; and (5) communicating [4], [5]. The scientific approach has advantages, it can: (1) improve student learning outcomes; (2) form students' skills in solving a problem systematically; (3) create learning conditions in which students feel that learning is a necessity; (4) train students in expressing and communicating ideas; (5) develop students' character and emotional intelligence [6].

One of the goals of improving the quality of learning is to improve student achievement. Learning achievement is an academic result that has been achieved by students in the knowledge, understanding, and skills of certain materials as measured by standardized tests after following a series of learning processes. [7], [8]. In addition to learning achievement, teachers also need to pay attention to students' emotional intelligence while they are studying mathematics. Emotional intelligence is a person's ability to realize, feel, understand, motivate oneself, and others [9]. Emotional intelligence also means the ability to control yourself and others. A person's emotional intelligence includes self-awareness, 
self-regulation, empathy, motivation, and social skills [10], [11]. The aspects of emotional intelligence can affect student learning outcomes [12], [13].

There have been many research results that concluded that CTL has a positive effect on student learning outcomes [14], [15]. Likewise, the scientific approach also has a positive influence on student learning outcomes [16]. There are also research results comparing the two approaches. However, it does not compare in terms of learning achievement and emotional intelligence of junior high school students in learning the topic of solid geometry.

Theoretically, by paying attention to the learning steps of the two approaches, researchers suspect that the scientific approach is better than the contextual approach in improving student learning achievement. However, the increase in emotional intelligence is likely not significantly different. To obtain empirical evidence for this assumption, the researcher conducted a study to examine the comparison of the effectiveness of the two approaches in terms of increasing student learning achievement and emotional intelligence. The benefit of this research is that mathematics teachers obtain more complete information regarding these two learning approaches.

\section{RESEARCH METHOD}

\subsection{Type of Research}

This type of research was a quasi-experiment. Researchers provided treatment to two equal classes. The equivalence of the two classes was known from the pretest results and the prescale score of the emotional intelligence of the two classes. Researchers used Manova with a significance level of $\alpha=5 \%$ to test the mean similarity of the pretest results of the two variables in the two classes. Randomly, the researcher assigned one class as the experimental class 1 which received contextual learning, and the other class as the experimental class 2 which received learning using a scientific approach.

\subsection{Place and Time of Research}

This research was conducted at MTs N (Islamic Junior High School) 1 Boyolali, Central Java, Indonesia, on March 3, 2020 - March 26, 2020. Research to test both approaches was carried out in six meetings. The total meeting was 15 hours.

\subsection{Population and Sample}

The population included all grade VIII students consisting of 10 classes at MTs Negeri 1 Boyolali in the 2019/2020 school year. While the sample in this study was class $\mathrm{C}$ and class $\mathrm{G}$ from class VIII MTs N 1 Boyolali, the 2019/2020 school year. Class C, hereinafter referred to as the Scientific class, had 36 students. Meanwhile, class $\mathrm{G}$ hereinafter referred to as Contextual class, had 37 students.

\subsection{Research Design}

This study used a pretest-posttest design with a nonequivalent control-group design. The steps in this study include: (1) determining the experimental class 1 and experimental class 2; (2) giving questionnaires and pretest to the two classes; (3) applying a contextual approach to the experimental class 1 and scientific learning in the experimental class 2; (4) giving questionnaires and posttest to the two classes; (5) analyzing data; (6) conclude. Teachers who taught in both classes were researchers themselves. The topic in both classes was also the same, namely solid geometry.

\subsection{Data Collection Technique and Instrument}

Researchers used the pretest and posttest questions to measure the increase in student achievement and used the prescale and post scale to measure the increase in students' emotional intelligence scores. The instrument for measuring learning achievement consisted of 15 multiple-choice items. While the instrument for measuring students' emotional intelligence consisted of 32 statement items. Both instruments are classified as valid and reliable. Data collection was carried out before and after learning. The content outlines for the learning achievement instruments are presented in Table 1 below. 
Table 1. Students learning achievement content outline

\begin{tabular}{|c|c|c|c|}
\hline \multirow{2}{*}{ Basic competencies } & \multirow{2}{*}{ Indicator } & \multicolumn{2}{|c|}{ Question number } \\
\hline & & Pretest & Posttest \\
\hline \multirow{8}{*}{$\begin{array}{l}\text { Distinguish and } \\
\text { determine the surface } \\
\text { area and volume of flat } \\
\text { side spaces (cube, } \\
\text { rectangular solid, prism, } \\
\text { and pyramid) }\end{array}$} & State the elements and properties of cube and rectangular solid & 1,2 & 1,2 \\
\hline & State the elements and properties of prism and pyramid. & 3 & 3 \\
\hline & State cube and rectangular solid nets & 4 & 4 \\
\hline & Mention prism and pyramid nets & 5 & 5 \\
\hline & Determine the surface area of cube and rectangular solid & 6,7 & 6,7 \\
\hline & Determine the surface area of prism and pyramid & 8,9 & 8,9 \\
\hline & Determine the volume of cube and rectangular solid & 10 & 10 \\
\hline & Determines the volume of prism and pyramid & 11 & 11 \\
\hline \multirow{4}{*}{$\begin{array}{l}\text { Solve problems related } \\
\text { to the surface area and } \\
\text { volume of a flat side } \\
\text { space (cube, rectangular } \\
\text { solid, prism, and } \\
\text { pyramid) and their } \\
\text { combinations. }\end{array}$} & $\begin{array}{l}\text { Solve everyday problems related to surface area and volume of } \\
\text { rectangular solid. }\end{array}$ & 12 & 12 \\
\hline & $\begin{array}{l}\text { Solve everyday problems related to the surface area and volume of a } \\
\text { cube. }\end{array}$ & 13 & 13 \\
\hline & $\begin{array}{l}\text { Solves everyday problems related to the surface area and volume of } \\
\text { the prism. }\end{array}$ & 14 & 14 \\
\hline & $\begin{array}{l}\text { Solve everyday problems related to the surface area and volume of } \\
\text { the pyramid. }\end{array}$ & 15 & 15 \\
\hline
\end{tabular}

Based on Table 1 above, it can be seen that the learning achievement content online consists of 15 multiple choice questions, and the indicators for pretest questions are the same as indicators for posttest questions. The content outlines for the emotional intelligence instruments are presented in Table 2 below.

Table 2. Emotional intelligence content outline

\begin{tabular}{|c|c|c|c|}
\hline \multirow{2}{*}{ Aspect } & \multirow{2}{*}{ Indicator } & \multicolumn{2}{|c|}{ Number } \\
\hline & & Positive & Negative \\
\hline \multirow[t]{3}{*}{ Self-awareness } & Know ourselves & 1,2 & 17,18 \\
\hline & Recognizing what things affect your emotions & 3 & 19 \\
\hline & Recognize the impact of each action & 4 & 20 \\
\hline \multirow[t]{2}{*}{ Self-regulation } & Stay calm when things go wrong & 5 & 21 \\
\hline & Can manage emotions well & 6 & 22 \\
\hline \multirow[t]{3}{*}{ Motivate ourselves } & Can motivate ourselves & 7 & 23 \\
\hline & Trying to be better all the time & 8 & 24 \\
\hline & Don't get frustrated when you're down & 9,10 & 25,26 \\
\hline \multirow[t]{2}{*}{ Empathy } & Understand thinking from the other person's point of view & 11 & 27 \\
\hline & There is a desire to help others & 12,13 & 28,29 \\
\hline \multirow[t]{3}{*}{ Social skills } & Active in discussions with other people & 14 & 30 \\
\hline & Easy to get along & 15 & 31 \\
\hline & Able to lead others & 16 & 32 \\
\hline
\end{tabular}




\subsection{Data Analysis Technique}

Researchers used an independent sample test to compare the average increase in learning achievement and emotional intelligence scores of students from the two experimental classes. Hypothesis testing used a significance level of $\alpha=5 \%$ and by using the help of SPSS 16 software.

\section{RESULT AND DISCUSSION}

\subsection{Data Description and Hypothesis Testing Result}

Table 3 presents statistics for student achievement data. The maximum possible score for achievement is 100 , both for the pretest and posttest scores.
Table 3. Statistics of student achievement

\begin{tabular}{|l|c|c|c|c|}
\hline \multirow{2}{*}{ Data } & \multicolumn{2}{|c|}{ Contextual class } & \multicolumn{2}{c|}{ Scientific class } \\
\cline { 2 - 5 } & Pretest & Posttest & Pretest & Posttest \\
\hline Mean & 31.37 & 77.30 & 28.15 & 79.81 \\
\hline $\begin{array}{l}\text { Std. } \\
\text { deviation }\end{array}$ & 10.12 & 10.69 & 10.58 & 10.74 \\
\hline $\begin{array}{l}\text { Lowest } \\
\text { Score }\end{array}$ & 13.33 & 60 & 6.67 & 60 \\
\hline $\begin{array}{l}\text { Higest } \\
\text { Score }\end{array}$ & 53.33 & 93.33 & 53.3 & 93.33 \\
\hline
\end{tabular}

After obtaining the pretest and posttest data, the researcher calculated the increase in each student's score. Table 4 below will describe the outcomes of each of the learning achievement indicators which have increased.

Table 4. Achievement of each learning achievement indicator

\begin{tabular}{|c|c|c|c|c|c|}
\hline \multirow{2}{*}{ Indicators } & \multirow{2}{*}{ Number } & \multicolumn{2}{|c|}{ Contextual class } & \multicolumn{2}{|c|}{ Scientific class } \\
\hline & & Pretest & Posttest & Pretest & Posttest \\
\hline \multirow{2}{*}{$\begin{array}{l}\text { State the elements and properties of cube and } \\
\text { rectangular solid }\end{array}$} & 1 & 17 & 29 & 6 & 34 \\
\hline & 2 & 21 & 37 & 10 & 36 \\
\hline $\begin{array}{l}\text { State the elements and properties of prism and } \\
\text { pyramid. }\end{array}$ & 3 & 18 & 37 & 21 & 35 \\
\hline State cube and rectangular solid nets & 4 & 25 & 34 & 18 & 32 \\
\hline Mention prism and pyramid nets & 5 & 13 & 31 & 26 & 31 \\
\hline \multirow{2}{*}{$\begin{array}{l}\text { Determine the surface area of cube and } \\
\text { rectangular solid }\end{array}$} & 6 & 1 & 27 & 8 & 28 \\
\hline & 7 & 18 & 36 & 16 & 36 \\
\hline \multirow{2}{*}{$\begin{array}{l}\text { Determine the surface area of prism and } \\
\text { pyramid }\end{array}$} & 8 & 5 & 26 & 0 & 25 \\
\hline & 9 & 10 & 29 & 5 & 25 \\
\hline $\begin{array}{l}\text { Determine the volume of cube and rectangular } \\
\text { solid }\end{array}$ & 10 & 13 & 27 & 13 & 26 \\
\hline Determines the volume of prism and pyramid & 11 & 6 & 19 & 9 & 26 \\
\hline $\begin{array}{l}\text { Solve everyday problems related to surface area } \\
\text { and volume of rectangular solid. }\end{array}$ & 12 & 26 & 27 & 10 & 25 \\
\hline $\begin{array}{l}\text { Solve everyday problems related to the surface } \\
\text { area and volume of a cube. }\end{array}$ & 13 & 6 & 21 & 6 & 24 \\
\hline $\begin{array}{l}\text { Solves everyday problems related to the surface } \\
\text { area and volume of the prism. }\end{array}$ & 14 & 3 & 25 & 3 & 28 \\
\hline $\begin{array}{l}\text { Solve everyday problems related to the surface } \\
\text { area and volume of the pyramid. }\end{array}$ & 15 & 2 & 23 & 1 & 21 \\
\hline
\end{tabular}


After describing the achievement score of each indicator, it is necessary to know the increase in the score of each class. Increased score $=$ posttest score - pretest score. Table 5 below presents the score improvement statistics for the two classes.

Table 5. Statistics on the improvement of student learning achievement scores

\begin{tabular}{|l|c|c|}
\hline \multirow{2}{*}{\multicolumn{1}{c|}{ Data }} & Contextual class & Scientific \\
\cline { 2 - 3 } & Gain (Post-Pre) & Gain (Post-Pre) \\
\hline Mean & 45.95 & 52.22 \\
\hline Std. deviation & 12.35 & 12.39 \\
\hline Lowest Score & 26.66 & 26.67 \\
\hline Highest Score & 66.66 & 80.00 \\
\hline
\end{tabular}

From the statistics presented in the two tables, it can be assumed that the average increase in learning achievement in the scientific class was higher than the average increase in learning achievement in the contextual class. However, to find out whether these differences were significant, the researchers tested them. $\mathrm{H}_{0}$ : the average increase in learning achievement scores in the scientific class was less or equal to the average increase in learning achievement scores in the contextual class. $\mathrm{H}_{\mathrm{a}}$ : the average increase in the learning achievement score of the scientific class was greater than the average increase in the learning achievement score of the contextual class. The test uses a significance level of $\alpha=5 \%$. Using the independent sample test, the value of $\mathrm{t}=2.188$ and sig $(2$-tailed $)=0.032$ was obtained. Because $\frac{\text { sig }}{2}<0,05$ the hypothesis testing rejects $\mathrm{H}_{0}$ and concludes that the average increase in learning achievement scores in the scientific class was greater than the average increase in learning achievement scores in the contextual class. Table 6 shows the statistics for students' emotional intelligence scores. The maximum possible score for a student's emotional intelligence score is 160 , while the minimum score is 0 . Then, Table 7 describes the achievement of each indicator of emotional intelligence.
Table 6. Statistics from students' emotional intelligence scores

\begin{tabular}{|l|l|l|l|l|}
\hline \multirow{2}{*}{ Data } & \multicolumn{2}{|c|}{ Contextual class } & \multicolumn{2}{c|}{ Scientific class } \\
\cline { 2 - 5 } & Prescale & $\begin{array}{c}\text { Post } \\
\text { scale }\end{array}$ & Prescale & $\begin{array}{c}\text { Post } \\
\text { scale }\end{array}$ \\
\hline Mean & 107.86 & 111.78 & 103.47 & 110.11 \\
\hline $\begin{array}{l}\text { Std. } \\
\text { deviation }\end{array}$ & 15,71 & 11,26 & 10.33 & 12.23 \\
\hline $\begin{array}{l}\text { Lowest } \\
\text { Score }\end{array}$ & 69 & 93 & 80 & 76 \\
\hline $\begin{array}{l}\text { Higest } \\
\text { Score }\end{array}$ & 135 & 136 & 132 & 132 \\
\hline
\end{tabular}

Table 7. Achievement of each indicator of emotional intelligence

\begin{tabular}{|l|c|c|c|c|}
\hline \multirow{2}{*}{ Indicators } & \multicolumn{2}{|c|}{ Contextual class } & \multicolumn{2}{c|}{ Scientific class } \\
\cline { 2 - 5 } & Prescale & $\begin{array}{r}\text { Post } \\
\text { scale }\end{array}$ & Prescale & $\begin{array}{r}\text { Post } \\
\text { scale }\end{array}$ \\
\hline $\begin{array}{l}\text { Self- } \\
\text { awareness }\end{array}$ & 93,12 & 125,5 & 117,87 & 117,25 \\
\hline $\begin{array}{l}\text { Self- } \\
\text { regulation }\end{array}$ & 131,5 & 128,75 & 115,75 & 129 \\
\hline $\begin{array}{l}\text { Motivate } \\
\text { ourself }\end{array}$ & 127,37 & 117,87 & 111,25 & 118,75 \\
\hline Empathy & 117,67 & 120,5 & 108,5 & 117,67 \\
\hline Social skills & 128,33 & 112 & 126,33 & 125,83 \\
\hline
\end{tabular}

Table 8 below presents statistics on the increase in students' emotional intelligence scores. Increased score $=$ final score - initial score.

Table 8. Statistics on the improvement of students' emotional intelligence score

\begin{tabular}{|l|c|c|}
\hline \multirow{2}{*}{\multicolumn{1}{c|}{ Data }} & Contextual class & Scientific class \\
\cline { 2 - 3 } & Gain (Post-Pre) & Gain (Post-Pre) \\
\hline Mean & 3.92 & 6.63 \\
\hline Std. deviation & 5.04 & 8.06 \\
\hline Lowest Score & -9 & -7 \\
\hline Highest Score & 16 & 25 \\
\hline
\end{tabular}


From the statistics presented in the two tables, it can be assumed that the average increase in emotional intelligence scores of students in both classes is relatively the same. However, to find out whether the mean increase in emotional intelligence scores between the two classes was not significantly different, the researchers tested it. $\mathrm{H}_{0}$ : the average increase in the emotional intelligence score of students in the scientific class was the same as the average increase in the emotional intelligence score of students in the contextual class. $\mathrm{H}_{\mathrm{a}}$ : the average increase in the emotional intelligence score of students in the scientific class was not the same as the average increase in the emotional intelligence score of students in the contextual class. Testing uses a significance level of $\alpha=5 \%$. Using the independent sample test, the value of $\mathrm{t}=2.72$, and sig (2-tailed) $=0.09$ was obtained. Because $\frac{\text { sig }}{2}<\frac{\alpha}{2}$ the hypothesis testing accepts $\mathrm{H}_{0}$ and concludes that the average increase in the emotional intelligence score of students in the scientific class was the same as the average increase in the emotional intelligence score of students in the contextual class.

\subsection{Discussion}

Being skilled emotionally can make us more adaptable, flexible, and emotionally mature. Sagala [17] suggested that intelligence is one aspect that teachers need to know to help students with learning difficulties. According to Uno [18], emotional intelligence skills work in synergy with cognitive skills, people who are high achievers have both. Uncontrolled emotions can make smart people act stupid. Without emotional intelligence, people will not be able to use their cognitive skills to their maximum potential. Both learning achievement and emotional intelligence are equally important in learning mathematics. Therefore, it is necessary to determine which approach is more effective for increasing achievement and emotional intelligence.

The results of testing this hypothesis were following the researcher's hypothesis. Theoretically, the scientific approach steps have more potential to improve student achievement. This is following the research of Atsnan \& Gazali [19] which states that the scientific approach will lead to the creation level which of course has an element of creativity in it. Also, the steps in the scientific approach consist of observing, questioning, gathering information, reasoning, and communicating the ability to improve students' problem solving and creative thinking abilities [20]. This ability will greatly affect student achievement and learning outcomes. When students observe what the teacher says and have the opportunity to ask everything they want to know, students begin to learn and to understand the concepts taught by the teacher. This is the initial stage of learning that can arouse student curiosity. The teacher deliberately designed the questioning stage. This is the advantage of the scientific approach compared to the contextual approach. The data from this study support this hypothesis. Using a significance level of $\alpha=$ $5 \%$, the researchers concluded that the average increase in student achievement in the scientific class was more than the average increase in learning achievement in the contextual class.

Furthermore, when viewed from Table 4, it was known that the results of the achievements in the scientific class showed a quite drastic increase in terms of the number of students who answered correctly. This of course has a positive impact on improving student learning outcomes. The results of this study are following the research conducted by Suhendar and Widjajanti [16] which shows the various advantages of the scientific approach. One of the advantages concluded from the results of their research is that the scientific approach can improve student achievement and stimulate student selfconfidence and student interest in mathematics.

This result was different from the result of Sulistyo's research [21]. Sulistyo's research concluded that the CTL approach is more effective than the scientific approach in learning the topic of "Opportunities" in terms of student achievement and motivation. The thing that could cause this difference in results is probably because Sulistyo's research was conducted in 2017. At that time the scientific approach was still new for teachers and students. There are allegations that students are not used to asking questions.

In the emotional intelligence variable, when viewed from the achievements of each indicator in Table 7 , there is an increase and decrease in each indicator in the contextual and scientific class so that indirectly it causes no significant difference in increase because both classes have both increased and a decrease in the mean score for emotional intelligence indicators. To increase students' emotional intelligence, the results of this study also support the researcher's hypothesis. The increase in students' emotional intelligence scores in the two classes did not differ significantly. The factors that cause it, among others, are that in both classes the teacher provides opportunities for students to discuss. This discussion activity trains students to learn to hold back and respect the opinions of friends [6], [10].

Although the results of this study conclude that the scientific approach was better than the contextual approach when viewed from the average increase in learning achievement of junior high school students on the topic of solid geometry, mathematics teachers need to be aware of several things. First, the advantages of the scientific approach are at the observing and questioning stage. If the teacher is unable to "turn on" this stage, likely, the increase in learning achievement in the two classes will not be significantly different. Second, teachers need to provide adequate learning resources, including preparing good worksheets, because in the scientific approach students have the opportunity to reason using learning resources prepared by the teacher. 


\section{CONCLUSION}

There are two results of this study. First, the scientific approach was significantly better than the contextual approach in improving junior high school students' learning achievement on solid geometry. Second, there was no significant difference between the scientific and contextual approaches in terms of increasing students' emotional intelligence.

The advantage of the scientific approach compared to the contextual approach lies in the observing and questioning stage. If the teacher can carry out this stage properly so that it can arouse student curiosity, student learning achievement can likely increase. Therefore, the researcher suggests mathematics teachers prepare for both stages well.

\section{ACKNOWLEDGMENTS}

The authors would like to thank the Directorate of Research and Community Service, the Ministry of Research and Technology of Republic Indonesia, for the funding of the grant research of this 2020 graduate program.

\section{REFERENCES}

[1] S. Sears, Introduction to Contextual Teaching and Learning. Phi Delta Kappa Educational Foundation, 2003.

[2] M. L. Crawford, "Teaching Contextually: Research, Rationale, and Techniques for Improving Student Motivation and Achievement in Mathematics and Science," pp. 3-14, 2001.

[3] B. P. Smith, "Instructional Strategies in Family and Consumer Sciences: Implementing the Contextual Teaching and Learning Pedagogical Model," $J$. Fam. Consum. Sci. Educ., vol. 28, no. 1, pp. 23-38, 2010.

[4] S. S. Carey, A Beginner's Guide to Scientific Method A Beginner 's Guide to Scientific Method. Holly J. Allen, 2004.

[5] Kemendikbud, Konsep Pendekatan Scientific. Jakarta: Kementerian Pendidikan dan Kebudayaan RI, 2013.

[6] A. Machin, "Implementasi Pendekatan Saintifik, Penanaman Karakter dan Konservasi Pada Pembelajaran Materi Pertumbuhan," J. Pendidik. IPA Indones., vol. 3, no. 1, pp. 28-35, 2014, doi: 10.15294/jpii.v3i1.2898.

[7] P. James Kpolovie, A. Igho Joe, and T. Okoto, "Academic Achievement Prediction: Role of Interest in Learning and Attitude towards School," Int. J. Humanit. Soc. Sci. Educ., vol. 1, no. 11, pp. 73-100, 2014, [Online]. Available: www.arcjournals.org.
[8] Fahrurozi and A. Mahmudi, "Pengaruh PBM dalam Setting Pembelajaran Kooperatif Tipe STAD dan GI terhadap Prestasi Belajar dan Kecerdasan Emosional Siswa," J. Ris. Pendidik. Mat., vol. 1, no. 1, pp. 1-11, 2014.

[9] S. Mcpheat, Emotional Intelligence. 2017.

[10] D. Hume, Emotions and Moods. New York, 1983.

[11] D. Goleman, Working With Emotional Intelligence. 2003.

[12] D. Goleman, Emotional Intelligene: Why it Can Matter More Than IQ. 2009.

[13] M. Syawahid and H. Retnawati, "Pengembangan Perangkat Pembelajaran Matematika Terintegrasi Dengan Pengembangan Kecerdasan Emosional Dan Spiritual," J. Ris. Pendidik. Mat., vol. 1, no. 1, p. 12, 2014, doi: 10.21831/jrpm.v1i1.2654.

[14] R. H. Setiawan and I. Harta, "Pengaruh Pendekatan Open-Ended Dan Pendekatan Kontekstual Terhadap Kemampuan Pemecahan Masalah Dan Sikap Siswa Terhadap Matematika," J. Ris. Pendidik. Mat., vol. 1, no. 2, p. 241, 2014, doi: 10.21831/jrpm.v1i2.2679.

[15] N. Afni and Hartono, "Contextual teaching and learning (CTL) as a strategy to improve students mathematical literacy," J. Phys. Conf. Ser., vol. 1581 , no. 1 , 2020, doi: 10.1088/1742$6596 / 1581 / 1 / 012043$.

[16] U. Suhendar and D. B. Widjajanti, "The Comparison of the Effectiveness of Scientific and PMRI Approaches Based on the Achievement, Interest, and Self-Confidence of Students of Grade VII," vol. 11, no. 1, pp. 91-101, 2016.

[17] S. Sagala, Concept and Importance of Learning. Bandung: Alfabeta, 2010.

[18] H. Uno, New Oriental in Psychology of Learning. Jakarta: Earth Literacy, 2010.

[19] M. F. Atsnan and R. Y. Gazali, "Penerapan Pendekatan Scientific Dalam Pembelajaran Matematika Smp Kelas Vii Materi Bilangan ( Pecahan )," J. Pendidik., vol. I, no. I, pp. 978-979, 2013.

[20] Mustakim, "Implementasi Pembelajaran Pemecahan Masalah dengan Pendekatan Saintifik Untuk Meningkatkan Kemampuan Berpikir Siswa Kelas VII SMP N 2 Patean,” vol. 16, no. 1, pp. 15$28,2015$.

[21] D. Sulistyo, "komparasi keevektifan pendekatan Cotextual Teaching and Learning dan Scientific dalam pembelajaran peluang ditinjau dari motivasi dan prestasi belajar matematika siswa." Tesis. Universitas Negeri Yogyakarta., 2017. 